\title{
Kernos
}

Revue internationale et pluridisciplinaire de religion grecque antique

$15 \mid 2002$

Varia

\section{Discerning Early Minoan cultic trends: the archeological evidence}

\section{Eleni Georgoulaki}

\section{OpenEdition \\ Journals}

Electronic version

URL: http://journals.openedition.org/kernos/1359

DOI: 10.4000/kernos. 1359

ISSN: 2034-7871

\section{Publisher}

Centre international d'étude de la religion grecque antique

\section{Printed version}

Date of publication: 1 January 2002

ISSN: 0776-3824

\section{Electronic reference}

Eleni Georgoulaki, «Discerning Early Minoan cultic trends: the archeological evidence », Kernos [Online], 15 | 2002, Online since 21 April 2011, connection on 01 May 2019. URL : http:// journals.openedition.org/kernos/1359; DOI : 10.4000/kernos.1359 


\section{Discerning Early Minoan cultic trends: the archeological evidence*}

\section{Introduction}

Minoan religion remains largely obscure owing to the absence of relevant written sources ${ }^{1}$. In fact, detailed pictures of beliefs and practices in the Aegean religion are included in the relevant bibliography.

L. Goodison has made a study on the symbolism of regeneration in the early Aegean ${ }^{2}$. She points out the contracted position of the dead body, the possible use of pigment (?), the change from care to disregard of skeletal remains after a certain period, the tendency to keep the deceased close to the settlement, the possible recycling of bones in ritual (?) and the existence

* Special abbreviations :

- Branigan, Politeia: K. Branigan, "Social Tranformations and the Rise of the State in Crete", R. Laffineur \& W-D. Niemeier (eds), Politeia, Society and State in the Aegean Bronze Age. 5th International Aegean Conference (Heidelberg, 10-13 April 1994), Aegaeum 11 (1995), p. 33-42, pl. IV-V.

- Dickinson, Bronze Age: O.T.P.K. Dickinson, The Aegean Bronze Age, Cambridge, 1994.

- Gesell, Town cult: G. Geseld, Town, Palace and House Cult in Minoan Crete (SIMA 67, 1985).

- Muhly, MLT: P. Metaxa-Muhly, Minoan Libation Tables, Bryn Maur College Ph.D. 1981.

- Nowicki, Aegean Arcbaeology 1 (1994): K. Nowicki, "Some Remarks on the Pre- and Protopalatial Peak Sanctuaries in Crete", Aegean Archaeólogy 1 (1994), p. 31-48 fig. 1-8.

- Rutkowski, Petsofas: B. Rutkowski, Petsofas, a Cretan Peak Sanctuary Warsaw (Studies and Monographs in Mediterranean Archaeology and Civilization 1, 1991)

- Rutkowski, Cult Places: B. Rutkowski, The Cult Places of the Aegean, New Haven / London, 1986.

- Rutkowski, Aegean Arcbaeology 1 (1994): B. Rutkowski, "Minoan Caves: The Main Cult Area", Aegean Arcbaeology 1 (1994), p. 26-30.

- Peatfield, OAth 32 (1990): A.A.D. Peatrield, "Minoan Peak Sanctuaries: History and Society", V 18 (1990), p. 117-131.

- Watrous, Politeia: L.W. Watrous, "Some observations on Minoan Peak Sanctuaries", in R. Laffineur \& W-D. Niemeier (eds), Politeia, Society and State in the Aegean Bronze Age. 5th International Aegean Conference (Heidelberg, 10-13 April 1994), Aegaeum 11 (1995), p. 395-402.

1 P. Muhly argues rightly that we know neither why Minoans chose to worship in certain types of shrine nor why the diverse types of cult places followed different patterns in their geographical distribution and chronological development (MUHLY, MLT, p. 355).

2 L. Goodison, Death, Women, and the Sun: Symbolism of Regeneration in Early Aegean Religion London, 1989 (BICS Suppl. 53), p. 23-38. 
at cemeteries of pavements (sites of generalised rituals [?]); according to her, these factors become coherent "if seen as reflecting a belief to the rebirth of the dead". Furthermore, on the account of the E. orientation of the Minoan circular tombs, she suggests the association of Minoan funerary beliefs with the movements of the sun. Finally, on the account of the boat representations $^{3}$, she concludes a special symbolic significance for boats on one hand, and the connection between the sun, the boat (form of transport) and the beliefs concerning the dead, on the other. With special reference to sea, C. Boulotis notes that several cults, handed down to us from the Homeric epics onward, some surviving even to the present day, presuppose a long tradition undoubtedly well rooted in Aegean prehistory ${ }^{4}$.

Unfortunately, a large proportion of the above suggestions depends on accepting questionable hypotheses ${ }^{5}$. Still, the process of extrapolating earlier forms of religion from later sources or other cultures can be hazardous ${ }^{6}$.

Since our main access to specific cult practices depends on questionable interpretations of fragmentary evidence, we could arrive at a few secure conclusions about the cultic aspect of Minoan religion. We could agree with O. Dickinson that the Bronze Aegean societies might share the belief, common to farming cultures, that there existed supernatural powers controlling the weather, the productivity of the soil and the fertility of living creatures. Their function would effectively be to secure the survival of the community. The methods of propitiation used would be parallel to those

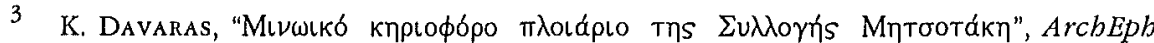
(1984), p. 55-95. Minoan and Greek Civilisation from the Mitsotakis collection, N.P. Goulandris Foundation-Museum of Cycladic Art, Athens, 1992, p. 107-108; E.

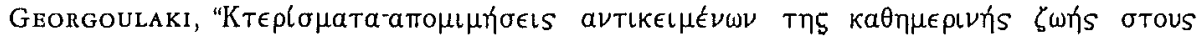

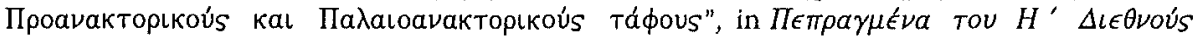

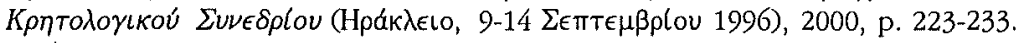

4 C. Boulotis, "The Aegean Area in Prehistoric Times: Cults and Beliefs about the Sea", in A. Delivorrias (ed.), Greece and the Sea. Catalogue of the exbibition, onganized by the Greek Ministry of Culture, the Benaki Museum, the national Foundation de Niewerk (Amsterdam, 29 October-10 December 1987), Amsterdam, 1987, p. 20.

5 Dickinson argues, that according to Evan's influential model of Minoan religion, the original form of religion over a wide area of the ancient world was centred on a dominant goddess of fertility, whose young consort's annual death and rebirth symbolised the decay and re-growth of vegetation (Bronze Age, p. 257).

6 Rutkowski suggests that the gods of the sky would be venerated on top mountains because a similar phenomenon occurs among many people of Asia, Africa and Europe (Rutkowski, Cult Places, p. 91). Peatfield extrapolates certain forms of Minoan religion from Japanese beliefs but he recognises that a "detailed theology of comparative beliefs is not recoverable within the limitations of Minoan archaeology" (PEATField, OAth 32 [1990], p. 125-126, 130). On the basis of iconographic similarities between Minoan and Egyptian items, Watrous has recently proposed an Egyptian influence on the Minoan peak shrines (Warrous, Politeia, p. 395-402). 
universally recorded: at public or private ceremonies, these powers would be invoked and be given gifts ${ }^{7}$.

We can be reasonably certain that the votive found in the Minoan sanctuaries would be personal offerings. The believer would be moved by genuine devotion and religious feeling. But there is no way of affirming whether the gift was left behind in thanks for the satisfaction of a need or in advance of a desired favour. We can only speculate on the reasons that prompted the dedication of some types of objects only in certain periods or at certain places ${ }^{8}$. Besides, certain interpretations proposed in the bibliography, regarding the identity of the visitors - rich town people, nomadic shepherds, pastoralists etc. -, the number or the exact time of visits - annual, seasonal, etc. -, that the Minoans made to the sanctuaries ${ }^{9}$, depend on dubious assumptions. On the basis of the available evidence it seems difficult to draw a firm conclusion on both the identity of the visitors and the frequency of their visits: whether they visited the sanctuaries informally, at any time or, large-scale ceremonies happened at certain times.

Moreover, one can imagine that as the state developed, the more important divinities might have begun to be organised to pantheons and would increasingly acquire individual personalities and functions ${ }^{10}$. Still, it is very hard to tell if the Minoan pantheon involved one or more separate independent deities, concerned with special domains. P. Muhly points out that many studies have emphasised the differences in the nature of the finds in various sanctuaries and have considered them as implications of the different nature of the divinities worshipped there. She rightly argues that these speculations have partly arisen from an uncritical evaluation of the evidence $^{11}$.

7 Dickinson, Bronze Age, p. 258-259.

8 MUHLY, MLT, p. 355. B. Rutkowski thinks that the worshippers might call attention to their sufferings, not only through the "votive limbs" but also, by focusing on certain parts of the body and exaggerating their size. Nevertheless, the proof of the healing

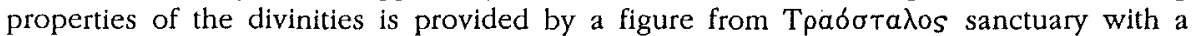

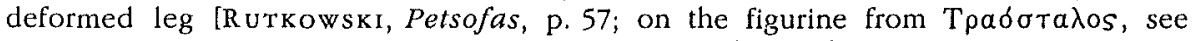
K. Davaras, Guide to Cretan Antiquities, Park Ridge, 1976, p. 246 fig. 139].

9 For similar theories, see Rutkowski, Cult Places, p. 91; id., Petsofas, p. 52-53; id., Aegean Archaeology 1 (1994), p. 29-30.

10 Dickinson, Bronze Age, p. 259.

11 Muhly, MLT, p. 354-355. Peatfield thinks that peak shrines would be places to which the deity was summoned (OAth 32 [1990], p. 120). B. Rutkowski believes that the cults of nature divinities connected with fertility rites can be traced back to the period preceding the MMI period (Petsofas, p. 52-53). With special reference to peak shrines, the same author suggests that the Minoans invested the divinity who appeared on the mountains not only with a woman's shape but also with an aniconic form (Cult Places, p. 91), whereas natural cave "architecture" would make the caves a good place for the worship of chthonic divinities (Aegean Archaeology 1 [1994], p. 29-30). Moreover he argues that, probably in MMI, another deity began to be worshipped, that is to say the 


\section{Cult Places}

The main attempts to discern Early Minoan cultic trends have focused on tombs as centres of communal religious activity ${ }^{12}$. Gesell argues that there

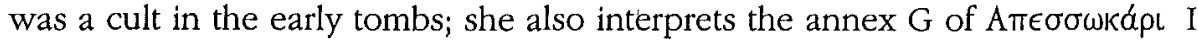
as a pillar-shrine and thus considers that the Pillar-room type of sanctuaries appears for the first time in the Old Palace period ${ }^{13}$. According to Peatfield, the EM tombs were the main religious focus for their individual communities. The votive limbs of the peak sanctuaries would be prefigured by offerings of figurines and foot-amulets in the EM tombs. The tomb shrines would go out of use as the peak sanctuaries come into use. Minoan religion would be a fertility religion. A feature of the fertility religions would be linked with the ancestor worship ${ }^{14}$. We would agree with Dickinson, that such theories present an impressionistic picture of the evidence and do not clearly distinguish between evidence that might relate to ceremonies in honour of the dead, and more general religious activity ${ }^{15}$.

Nevertheless, there is no evidence that the Minoans practised a cult of the dead; this hypothesis is reinforced by the absence of clay models shaped after human limbs from the funerary contexts. These items would have probably been left in thanks or in advance for the satisfaction of a need. But unlike the divinity, the deceased would be considered unable to care of the essential needs of the living and consequently did not receive similar votive. Thus, the cult and funerary material presents the differentiated attitude of the Minoans towards the dead and their divinity or divinities.

In fact, sites of repeated ritual activity, associated with collective cult practices are hard to find and there is little agreement on the nature of early Minoan shrines. However, many classes of items with religious affinities, figurines, anthropomorphic and zoomorphic vases and Minoan cult symbols

divine husband of the goddess. In his honour, high pillars were erected before the sanctuaries. Until the end of LMI the domestic sanctuaries were confined to the private houses and palaces, where the cult of the Household Goddess was practised. The great flourishing of the Minoan culture was put to a sudden stop by the eruption of the Thera volcano in LMI. At this time, too, the faith in the power of the deities of heaven who appeared in the peak sanctuaries was severely shaken. Thus, people looked for help from the deities in the caves (Cult Places, p. 231-232).

$12 \mathrm{~K}$. Branigan suggests the practice of communal non-funerary ritual in Prepalatial tombs. He also argues that the rituals related to the cult of the Snake Godess were practised in the Messara cemeteries (Branigan, Politeia, p. 36-37; ead., Dancing with Death, Amsterdam, 1993, p. 127-136. According to N. Marinatos, the cult around the tombs represents the earliest type of communal ritual in Minoan Crete. Secondary burial would provide an occasion of communal gatherings in the cemeteries (N. MARINATOS, Minoan Religion, Ritual, Image and Symbol, University of South Carolina, 1993 [Studies in Comparative Religion], p. 13-15, 18-19, 30-31).

13 Gesell, Town cult, p. 1, 9, 15.

14 PeAtrield, OAth 32 (1990), p. 124-125.

15 Dickinson, Bronze Age, p. 260. 
(double axe) have been found in Prepalatial tombs. Thus, already in this period, it is possible to document examples of features that were to be part of the Minoan religious system for a very long time ${ }^{16}$. We think that the disposal of items with overtly religious affinities - figurines, vases with aperture, rhyta ${ }^{17}$, as accompanying goods indicates that worship - while the deceased was still alive -, would be private. G. Gesell notes that Minoan cult must have been developed in the houses and the towns, but the evidence is not extensive, since later towns were built over the early settlements. At Múpros settlement, a female pouring vase has been discovered standing on a bench within a building of the Prepalatial settlement; according to the excavator, the arrangement of the room and the pose of the vase suggests the cult identification ${ }^{18}$. However, there is a controversy over the nature of this shrine; we do not know whether the shrine served a single family / household or the whole community ${ }^{19}$.

The hypothesis of Dickinson that a number of open-air sites might have been associated with the performance of rites ${ }^{20}$ has been reinforced by the recent discoveries at $A \tau \sigma \iota \pi \alpha ́ \delta \epsilon S$-KopakıєS and $\Sigma \pi \eta \dot{\eta} \lambda \iota$, in the Rethymnon district. At $A \tau \sigma\left\llcorner\pi \alpha ́ \delta \epsilon\right.$ s there was a small sanctuary ${ }^{21}$. The waterworn pebbles brought from the river in the valley below were laid out to form a floor around an artificial earth platform, lined with schist-like stones. Vase fragments belonging to pouring vessels were plentiful around the platform. While cups, dishes, jars, lamps, and cooking pots were common at the site, animal bones were absent. On the lower terrace the votive figurines as well as cups and dishes were concentrated in the rock cleft. The pottery on the site is predominantly of Old Palace period and the shrine appears not to have been used after MMII. The material scattered along the valley reveals a pattern of small dispersed settlements. Peatfield suggests that these sites were served by the shrine ${ }^{22}$. Moreover, the location of the sanctuary at

16 Ibid., p. 260.

17 For further discussion on the vases with aperture, see E. Ggorgoulaki, "Minoan Anthropomorphic vases; Indications of Polytheism in the third Millenlum B.C?", in $110 \mathrm{~V}$

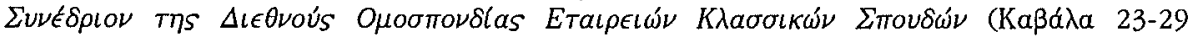

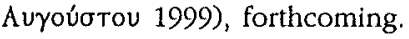

18 P. WARREN, Myrtos. An Early Bronze Age Settlement in Crete, ABSA Suppl. 7 (1972), p. 230-231. According to Gesell, built rooms containing fixed cupule stones - they are flagstones, set in the floor, on which a ring of slight circular depressions had been chipped -, might be identified with ritual places (Gesels, Town cult, p. 7. On the fixed

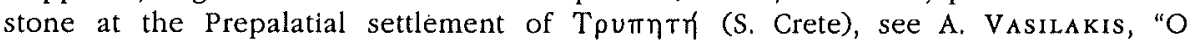

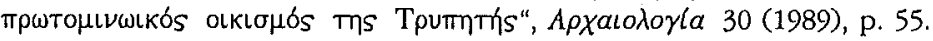

19 Branigan, Politeia, p. 36.

20 Dickinson, Bronze Age, p. 261-262.

21 J. Moody, "Ayios Vasilios Valley Survey Project", in J. Murly (ed.), One bundred years of American Archaeological Work on Crete, Athens, 2000, p. 187, fig. 240.

22 D. BLACKman, "Atsipadhes Korakias", ArchReports (1996-7), p. 118,120; EMI (but no EMII) pottery has also identified, but the relationship of that pottery with the later shrine 


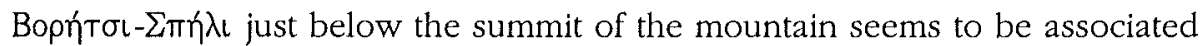
with the view. The shrine has a better view down onto the place where the Minoan settlement seems to have been. Pebbles, figurines and sherds were related to the natural rock features. The finds (cattle figurines, pottery) are similar to those of $A \tau \sigma \iota \pi \alpha ́ \delta \epsilon s$ but lamps and larger storage vessels are absent. The shrine is broadly dated in EMIII-MMI ${ }^{23}$.

Nowicki has investigated several sites where "peak shrines" have been discovered and points out that the pebble feature is a new criterion for their definition. Figurines and vessels would be deposited in, or around this feature. The concentration of pebbles and their distribution indicate that they were deposited during both the Prepalatial and Old Palace periods ${ }^{24}$. Watrous has proposed that certain areas, found next to Prepalatial settlements and covered with pebbles might have a cult destination. These "individual settlement shrines" would belong to the community ${ }^{25}$.

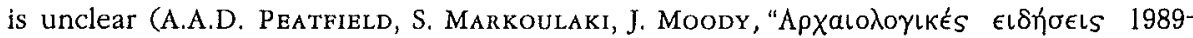

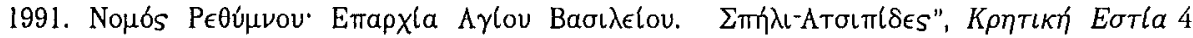
(1991-1993), p. 282-285; Chr. Morris, A.A.D. PeAtField, "Pottery from the peak sanctuary of Atsipadhes Korakias, Ay. Vasiliou, Rethymnon", in $\Pi \epsilon \pi \rho a \gamma \mu \epsilon \nu \alpha$ tov $Z^{\prime} \Delta \iota \epsilon \theta \nu o u ́ s$

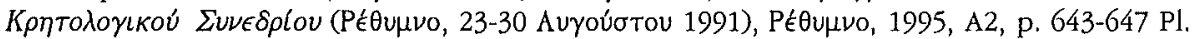
NA'-NE'; Chr. Morris, V. BATTEN, "Final Neolithic Pottery from the Atsipadhes Peak

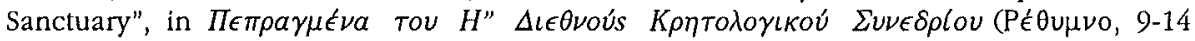
$\Sigma \epsilon \pi \tau \epsilon \mu \beta \rho(o v ~ 1996)$, PÉ $\theta u \mu \nu o, 2000$, A2, p. 373-382.

23 R. Tomlinson, "Atsipades Korakies Peak Sanctuary", ArcbReports (1994-1995), p. 64.

24 Concerning Гloúktas Karetsou refers to the significance of natural features and mentions the location of an altar nearby. At Ka $\phi($ - Nowicki suggests that the MM shrine would not be destroyed during the LMIIIC occupation -, the concentration of pebbles was associated with MM sherds and fragmentary figurines. Pebbles have been also found in settlements but, whilst the shrine sites reveal hundreds or thousands of pebbles, a limited number of this feature comes from habitation places. Nowicki makes some suggestions about the possible objects that could have stood at the place of the pebbles feature (pithos, baetyl) (Nowickr, Aegean Archaeology 1 [1994], 35-39; I. Karetsou, PAAH [1974], p. 232-234).

25 Recent excavation, made on the LM peak sanctuary of Tpaóraגos, revealed sea-

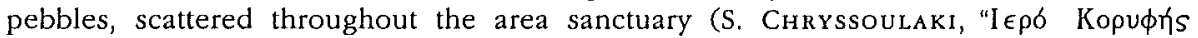

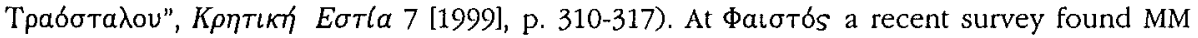

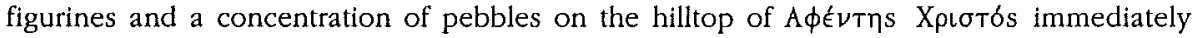
west of the excavated site (L. VANCE-WATrous, "The Origin and Iconography of the Late

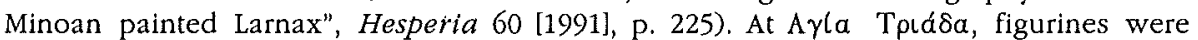
found on the low hilltop immediately $\mathrm{E}$. of the settlement (C. LAviosa, "Saggi di Scavo ad

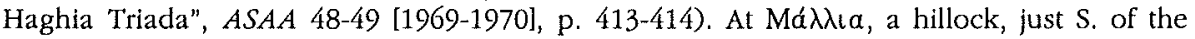
town, produced a figurine of a beetle, a find characteristic of peak sanctuaries (Rutkowski, Cult Places, p. 98 for bibliography). At Гoupvia, the recent survey has identified two concentrations of pebbles, pumice and Minoan sherds on the ridge top to

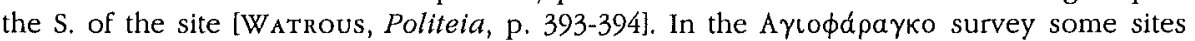
were identified by Branigan as minor hilltop shrines. Branigan believes that they represent the beginnings of the peak sanctuary tradition but he accepts that these sites do not conform to the criteria for identifying Middle Bronze Age peak sanctuaries. If we accept the identification of Branigan, it seems that these "cult places" were related to 
It seems therefore that there existed a cult beyond individual households: some cult localities (open-air sites [?] or comprising a building made of perishable material) - situated in rural areas -, would be scattered throughout the island, whilst each larger settlement would possess its own sanctuary. These settlement shrines would have served the whole community and to this extent might be called public. There is an overlap with peak sanctuaries, as far as it concerns the finds, with the important difference that settlement sanctuaries are not located on peak summits and are neither remote places of pilgrimage nor larger religious centres.

Peatfield and Nowicki have recognised a single type of cult places, that means the peak sanctuary, defined by its location on a mountain high above its surrounding region and by votive. In that sense, Peatfield rightly argues that these shrines were local, accessible and laid within the boundaries of agricultural exploitation. The commonly attested belief that the divine powers live in the mountains is not recoverable within the limitations of the Minoan data ${ }^{26}$. However, these characteristics could be applied in the case of settlement shrines. More successfully, Watrous makes a distinction between "regional sanctuaries" - we would call them "peak shrines" -, e.g. Гıoúkтas, Kó $\phi \iota v a s$ and Boúouvas ${ }^{27}$ and local examples, the "hilltop shrines" belonging to small communities - they might better be referred to as "settlement shrines". The settlement shrines were probably associated with the nearby community, whereas peak sanctuaries served an entire region. Because many of these smaller, hilltop shrines are unexcavated and often produce a restricted range and number of votive, they have not been identified as shrines ${ }^{28}$.

A peak shrine is located on the elevation dominating the area and visible from afar, distant from any settlement, hamlet, farmstead, etc. As a rule, there are no architectural remains, at least during the early periods. Finds involve pottery and figurines scattered over a restricted area. From the Old Palace period onwards, clay figurines become the standard class of votive offerings. Animal bones seem to be limited to the sites with New Palace period material on the surface ${ }^{29}$. The argument concerning the relative distance of peak

specific areas of territory and served family groups and hamlets or villages (D. BLACKMAN, K. Branigan, "Survey of the lower Catchment of Ayiofarango Valley", ABSA 72 [1977], p. 71-72).

26 PeatField, OAth 32 (1990), p. 120.

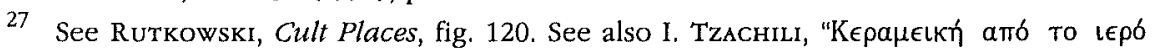

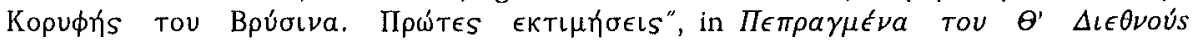

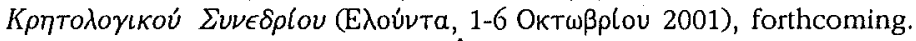

28 L. Watrous, $A J A 98$ (1994), p. 793-794. Watrous argues that the following sites would

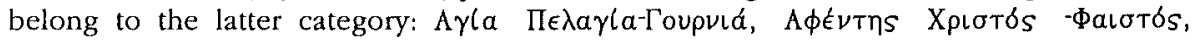

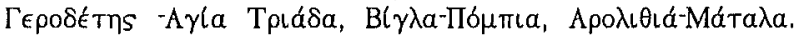

29 This is the definition recently proposed by Nowicki, which, as himself points out, is nothing more than that introduced by Rutkowski and Peatfield but supplemented by new data based on recent field investigations (Nowicki, l.c., p. 31, 34-35). For another 
shrines from the habitation places is confirmed by the recent excavation of Sakellarakis on Kúmpa - the distribution of these cult areas was not restricted only to Crete. According to Sakellarakis the site 'A $\gamma$ los $\Gamma \epsilon \omega$ ' $\gamma$ los situated on

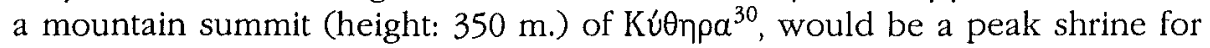

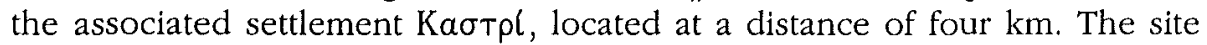
fulfils the criteria for the definition of peak shrines, that means eminence, visibility, accessibility and proximity to the settlement. Votives have been found associated with animal bones ${ }^{31}$.

In general, cult sites are better represented in MM period than the EM one. Old Palace period is the period of flourishing of peak shrines ${ }^{32}$. The plausible evidence for shrines in buildings and for cult deposits in some caves belong to that period. Shrines within towns, being an integral part of a building, have one or more connected rooms, usually with a subsidiary function, such as store-rooms or ante-room. At Mád $\lambda \iota a$, several kinds of "offering vessels" have been discovered in a room, located W. of the later palace, near to the houses of Quarter $D$; a relief double axe marked an inverted tripod vessel; the connection of the double axe - standard Minoan symbol - vase with an "offering table" establishes the cult use of the room (Old Palace period) ${ }^{33}$. The caves have produced relatively little material and were often above the snow-line, so only accessible for part of the year. Given the multiple use of certain caves $^{34}$, there is uncertainty as to whether

approach, see S. Soetens, A. SARris, S. TopouzI, "Peak sanctuaries in the Minoan cultural

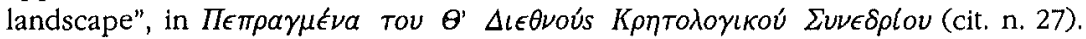

30 See J. Sakellarakis, "Minoan Religious Influence in the Aegean: the case of Kythera", ABSA 91 (1994), pl. 10.

31 The finds from the shrine include some clay figurines (both human and animals), abundant bronze figurines of "adorant type", bronze votive limbs, weapons, ornaments, miniature "horns of consecration", a miniature double axe. Some sherds of the beginning of MM period imply the foundation of the shrine at an early date but the period of its flourishing seems to be the New Palace period (J. Sakellarakis, "To Mivwḯó lepó

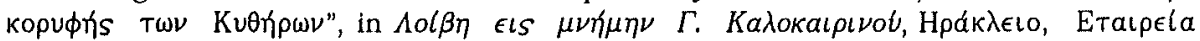

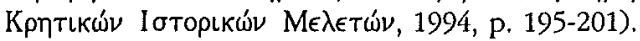

32 We would agree with Nowicki that "we should not speculate yet as to when people started to climb the mountains carrying with them votive offerings to be deposited on the summit. New excavations can still surprise us. Today we can only say that it may have happened somewhen between the EMII and III periods" [NowICKI, $l . c_{.}$, p. 40]. Recent excavation, made on the MMII peak sanctuary of Kopakopoúpı- $\Sigma \phi a ́ k \alpha$ (area of Zákpos), revealed pottery and figurines, scattered throughout the area sanctuary. It was a small, local shrine, which did not continue in use in the New-palace period ( $S$.

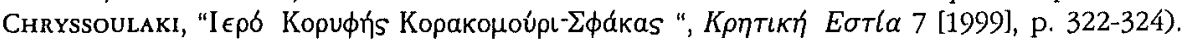

33 J.-C. Poursat, "Un sanctuaire du Minoen moyen II à Mallia", BCH 90 (1966), p. 514550; Gesell, Town cult, p. 9; see also Rutkowski, Cult Places, p. 158-161; Gesell, o.c., p. 915 , for further discussion about the town sanctuaries and bibliography.

34 Dickinson, Bronze Age, p. 42; J.D.S. Pendlebury, The Archaeology of Crete, London, 1939 , p. 22-23; T.F. STRASSER, Neolithic settlement and land-use on Crete, University of

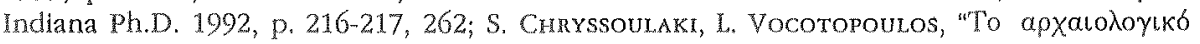


particular objects, found in them, are to be associated with the use of cave for cult or for other purposes, as well as the problem of dating them accurately. Rutkowski dates the beginning of worship in caves in MMIA, though sacred caves achieved their greatest popularity from MMIII onwards. Votive only begin in New Palace period. Nevertheless, not every cave used for habitation went on to become a shrine. The reasons why certain caves were regarded as sacred may be varied but it is no longer possible to be certain. Particular factors, such as the presence of water or natural concretions, found in many caves might be essential ${ }^{35}$.

During the New Palace period, the cult seems to be centralised at the few peak sanctuaries associated with the palaces and palatial towns. The settlement sanctuaries, which were associated with the smaller settlements or groups of farmsteads, would be abandoned after the end of the Old palace period ${ }^{36}$.

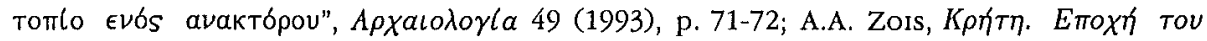

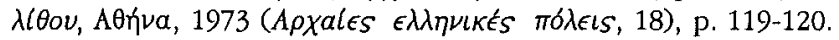

35 On the evolution in the function of certain caves, first being used as dwellingplaces, then as burial places and later as cult places, $c f$. Rutкowski, Cult Places, p. 65-66, 226-227. On the caves' date see B. Rutkowski, Aegean Archaeology 1 (1994), 26-27; L. TYReE, Cretan Sacred Caves: Archaeological Evidence, Ph.D., 1974, p. 64-70. P. Muhly makes a critical review of the conclusions reached by $E$. Tyree in her study and reexamines the available information; she points out that the evidence for the religious use

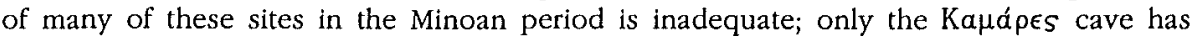
produced a substantial assemblage of finds which testify its cultic use in MMI-MMII period (MuhLy, MLT, p. 359-368). See also L. Tyree, "Minoan sacred caves: The natural and

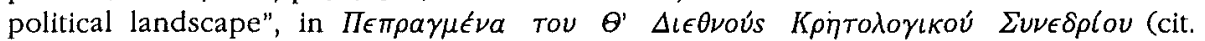
n. 27).

36 NowICKI, Aegean Archaeology 1 (1994), p. 41. At Гloúkтas, the stepped structure, built next to a deep chasm in the bedrock, probably served as an altar in the MMIB-II period. Most of the pottery from within the chasm dates to the Old Palace period. Next to the altar, was found a large stone kernos (with ca. 100 cupules) and, in a depression a "cache" of bronze double axes [reports for the excavations on Гıúktas appear in I. Karetsou, $P A A H$ (1974), p. 232, 247-249; PAAH (1975), p. 330-342; PAAH (1976), p. 408418; PAAH (1977), p. 419-420; PAAH (1978), p. 232-258; PAAH (1979), p. 280-281; PAAH (1980), p. 337-353; PAAH (1981), p. 405-408; PAAH (1984), p. 600-614; PAAH (1985), p. 286296]. It has been argued that peak shrines were part of the process of manipulating ideology by which the palace asserted its control of the palace. According to A. Peatfield, peak shrines symbolically unified the Minoan society of the Old Palace period ("Rural Ritual in Bronze Age Crete: the Peak Sanctuary at Atsipades", Cambridge Arcbaeological Journal 1 [1992], p. 61]. According to Dickinson, the commanding position and the quantities of material found at the peak shrines suggest that they were important communal cult centres (Dickinson, Bronze Age, p. 267). J. Wright argues that peak sanctuaries were first local places of cult. The interest of the palaces in manipulating these cults to their advantage would be a later phenomenon, manifested in the appearance of specifically palace-related artefacts: inscribed libation tables, and symbolic items such as the double axe (J. WRIGHT, "The Archaeological Correlates of Religion: Case Studies in the Aegean", in Laffineur-Niemergr, o.c., p. 346). 
From the available archaeological evidence about the finds in Minoan sanctuaries, it appears that the votive and cult equipment would be indicative of the economic and social diversity of the worshippers. For instance, uncommon and luxury offerings, such as seal stones bronze figurines, daggers and other objects of precious materials, suggest people who had access to these items.

Walberg has studied the types of vases from different cult places - caves, peak shrines, shrines in palaces and houses - and wonders whether some types are more frequent in sanctuaries than in secular contexts. The fact that many of the vessels from different types of shrines are similar indicates that the ritual would have been the same ${ }^{37}$. Watrous argues that, despite substantial variations in the offerings at the different regional and local settlement sanctuaries, the impression gained is that a similar cult was practised at all of these shrines. The settlement shrines would be part of the same phenomenon that produced the larger sanctuaries ${ }^{38}$.

Still, it is worth noting, that in the town shrines of the Old Palace period, most of the Minoan cult symbols - double-axe ${ }^{39}$, horns of consecration occur but are not common. No votive or display double axe $\mathrm{e}^{40}$ has appeared in this period. The religious motifs in pottery are sporadic on the early periods, but from the end of the Old Palace period onwards some fantastic animals appear, whereas the MMIII-LMI is the period of their most use ${ }^{41}$. Walberg believes that "MMIII represents a period of transition" in ritual ${ }^{42}$.

37 G. Walberg, "Early Cretan Sanctuaries: the Pottery", in T. Linders, G. Nordquist (eds), Gifts to the Gods. Proceedings of the Uppsala Symposium 1985, Uppsala, 1987, p. 172174. Recently, D. Jones has made a comparison of artifacts found in Minoan peak sanctuaries and sacred caves. He notes that "people" exercise a choice in the locational characteristics of a site, simply by selecting one site in preference to another, whatever the basis of that choice... Subsequent choices include... to construct buildings or other architectural features on the site... The cult equipment and... the votives would have offered repeated opportunities of choices, both in terms of repetition by each individual worshiper and choices by different individuals... the artifacts contain.. more information on religious ritual than do the site characteristics": D.W. JoNEs, Peak Sanctuaries and Sacred Caves in Minoan Crete: a comparison of Artifacts, Göteborg, 1999 (SIMA, 156), p. 40 .

38 Watrous, Politeia, p. 393-394. Other authors suggest the practice of different cults in the various Minoan shrines: B.C. Dietrich, Origins of Greek religion, Berlin, 1974, p. 297-298; Dickinson, Bronze Age, p. 272.

39 See the relief vase from Mallia shrine (Rurkowski, Cult Places, fig. 220).

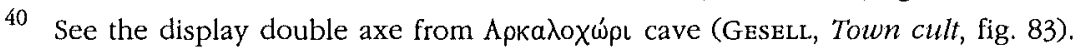

41 lbid., 62-63

42 G. WalberG, MMIII, a time of Transition, Göteborg, 1992 (STMA, 97), p. 137. 


\section{Conclusion}

We think that the difference concerning the political could reflect certain aspects of the cult practices: the scattered Prepalatial community sanctuaries could have been gradually substituted by major public shrines and greater palatial religious centres. We would further speculate that the tendency to centralisation and individualism would have been expressed in the cultic architecture, but a radical change in the religious beliefs does not seem to be the case. The same underlying beliefs would be held by the worshippers visiting the different types of shrines. From this base of belief, the forms the ritual took and the ceremonies involved differed in details, a fact resulting in the differences detected at the various shrine types ${ }^{43}$. We should keep in mind, that belief generally remains the same, while the structure and practice change ${ }^{44}$.

Eleni Georgoulaki

43 Some authors have suggested that the Minoans' view of their gods may have changed significantly during the two millennia of worship and religious experience: Dickinson, Bronze Age, p. 260; G. Walberg "Problems in the Interpretation of some Minoan and Mycenean Cult Symbols", in E. French, K. WArdLe (eds), Problems in Greek Prebistory. Papers presented at the Centenary Conference of the Birtish School of Archaeology at Athens, Manchester April 1986, Bristol, 1988, p. 211-212. However, Wright rightly argues that belief and practice (ritual) exist within a "structure", by which is meant the organisation and integration of religion with respect to society. As such, it should be understood that structure changes as society changes. As the structure of religion changes, so does practice. But within any religion belief tends to be an unchanging stage upon which practice and structure play. Thus the changing structures (the increasingly complex economic and administrative systems of Palatial Minoan Crete) might elaborate new practices, upon the unchanging Prepalatial belief system, which formed the underlying cosmology of the inhabitants of Crete (WRIGHT, o.c., p. 342, 347).

44 Still, it is possible that religious thought might evolve as well: after the so-called reoccupation or Postpalatial inhabitation, the Mycenaeans arrive in Crete. The Postpalatial period is a time of change and what survived in cult underwent considerable adaptation. It is not our intention to enter in details about this substantial subject, but we would like to note that some elements in cult might be the result of some mainland influence to Crete. Gesell points out that new developments in Postpalatial period include the goddess with upraised hands (dominating figure in the cult) and the hut urns but other cult objects continue to be Minoan in tradition (offering tables, figurines, rhyta, etc.) (Gesel., Town cult, p. 41-54 for further discussion and bibliographical references). For a different approach, see MUHLY, MLT, p. 354-355. 